\title{
MITIGATION OF URBAN HEAT ISLANDS : METEOROLOGY, ENERGY, AND AIR QUALITY IMPACTS \\ ヒートアイランドの緩和手法に関する研究：気象・エネルギー・大気質への影響
}

\author{
Haider TAHA*, Alan MEIER*, Weijun GAO** \\ and Toshio OJIMA*** \\ ハイデタハ, アランメイエア, 高 偉 俊, 尾島俊雄
}

\begin{abstract}
This paper presents results from energy, meteorological, and photochemical (air quality) modeling for the Los Angeles Basin, one of the largest and smoggiest urban regions in the U.S. and the world. Our simulations suggest that by mitigating urban heat islands, savings of 5 to $10 \%$ in peak utility load may be possible. In addition, heat island mitigation can reduce smog formation by $10-20 \%$ in summer, which is as effective as controlling emissions from all mobile sources in the region. For a typical late-August episode, our simulations suggest that implementing cool cities in the Los Angeles Basin would have a net effect of reducing ozone concentrations. Peak concentrations at 3 pm decrease by up to $7 \%$ (from 220 down to $205 \mathrm{ppb}$ ) while the total ozone mass in the mixed layer decreases by up to 640 metric tons (a decrease of 4.7\%). Largest reductions in concentrations at $3 \mathrm{pm}$ are on the order of $50 \mathrm{ppb}$ whereas the largest increases are on the order of $20 \mathrm{ppb}$. With respect to the National Ambient Air Quality Standard, domain-wide population-weighted exceedance exposure to ozone decreases by up to $20 \%$ during peak afternoon hours and by up to $10 \%$ during the daytime.
\end{abstract}

\section{Keywards: Heat island, Meteorology, Air quality, Simulation ヒートアイランド、気象、大気質、シミュレーション}

\section{INTRODUCTION}

The urban heat island phenomenon has been well documented and characterized and well researched for the past fifty years [1-9]. In Califormia, for example, peak urban air temperature has been going up by about $0.4^{\circ} \mathrm{C}$ per decade [10]. In Los Angeles, the annual high air temperature has increased by about $4^{\circ} \mathrm{C}$ since 1940 . Cities from all over the world exhibit a trend in temperature, though not necessarily of this magnitude. In Japan, urban heat islands in the Kansai and Kanto regions have also appeared and increased in intensity during the last several decades.

With increased air temperature, anthropogenic (e.g., evaporative or fugitive) and biogenic VOC emissions increase and so do NOx emissions from power plants and mobile sources[11,12]. In addition, the atmospheric photochemical reactions producing smog generally accelerate with temperature $[13,14,15]$. Measured data from Los Angeles show that there is no ozone exceedance above the National standard when air temperature is below $23^{\circ} \mathrm{C}$. Once this threshold is exceeded, more and more exceedances in ozone concentrations are observed.

It is thus clear that urban heat islands are unwanted in the mid- and low-latitudes and that some mitigation is needed. At the Lawnence Berkeley National Laboratory, we have been working on taking that one step beyond the characterization and study of urban heat islands, i.e., mitigating their detrimental effects. For example, several studies have demonstrated and quantified potential savings of $5-15 \%$ in cooling energy use due to increasing the albedo of building and urban surfaces $[16,17,18]$. In some cases, savings of $100 \%$ were reported. In parallel, meteorological modeling work that investigated the role of surface properties in mesoscale meteorology showed that largescale increases in albedo and vegetation cover (sometimes called "cool cities" strategies) can decrease ambient air temperatures $[19,20,21]$. Sudies by Taha and $\infty O-$ workers [11,13-15,22], show that implementing cool cities strategies will reduce urban air temperatures by up to $5^{\circ} \mathrm{C}$ in summer and, correspondingly, improve air quality by $10-20 \%$ (that is reducing exceedance exposure to ozone by $10-20 \%$ ).

The general implications of lower ambient temperatures include 1)a decrease in some photochemical reaction rates, 2).a decrease in temperature-dependent biogenic hydrocarbon emissions, 3).a decrease in evaporative losses of organic compounds from mobile and stationary sources, and 4) a decreased need for cooling energy, generating capacity, and, ultimately, emissions from power plants. Thus in this sense, cool cities have a potential for reducing ozone formation. However, decreasing the near-surface temperatures can also decrease the depth of the mixed layer at some locations in the airshed potentially trapping pollutants (in a shallower boundary layer), possibly resulting in higher ozone concentrations. Decreasing near-surface temperatures may also weaken the local circulation (e.g., sea or land breezes) which can cause a small increase in ozone concentrations in upper layers of the atmosphere $[14,15]$.

Thus heat island mitigation has broader benefits than usually considered, many of

* Staff Scientist, Lawrence Berkeley National Laboratory, California 94720, Ph. D.

カリフォルニアローレンスバークレー

${ }^{* *}$ Research Lecturer, Rise, Waseda University, Dr. Eng.

*** Prof., Dept. of Architecture, Waseda University, Dr. Eng. 
which translate directly into economic benefits. But the negative effects, if any, also need to be estimated, and thus the reason for atmospheric modeling. The direct impacts are easy to measure. However, the indirect atmospheric impacts are not easy to monitor, thus another reason for performing mesoscale modeling, as discussed in the rest of this paper.

This type of research, in which several models have been linked or run off-line, has not been undertaken for Japanese conditions. However, there is widespread interest among Japanese scientists to perform such research and modeling studies, e.g., Kim et al. (1997)[23], Ojima et al. (1995)[24], and Gao et al. (1994,1995)[25,26].

\section{METHODOLOGY}

The following sections describe our approach to modeling the energy, meteorology, and air quality implications of urban heat island mitigation as applied to the LoS Angeles Basin. We also mention the status of data needed to undertake similar analyses of various regions in Japan.

\subsection{SURFACE CHARACTERIZATION AND SURFACE MODIFICATIONS}

In order to trace and quantify the links described above, complex atmospheric models are needed. To simulate the meteorological impacts of heat island mitigation, a mesoscale meteorological model was used in this study. In this section, we describe the method of preparing surface characteristics data for input into these models.

The gridded surface characteristics input to the meteorological model was developed based on U.S. Geological Survey (USGS) data and also based on satellite data $[27,28]$ Tables 1 and 2 show values of thermophysical parameters as assigned in this study. For all urban land-use sub-categories, we assumed a soil moisture content (soil wetness) of
0.05 , density of $1.6 \mathrm{~g} \mathrm{~cm}^{3}$, thermal diffusivity of $0.0033 \mathrm{~cm}^{2} / \mathrm{s}$, and specific heat of 1.26 $\mathrm{J} / \mathrm{g} \mathrm{K}$. Other values are shown in the tables.

Some of these values and parameters could be used in simulating Japanese cities but others will need to be locally measured or generated. Soil moisture content, for example, could be generally higher in Japan. Anthropogenic heat flux will probably be different, too. Some local values for these parameters have been generated and used in simulations of the Kanto region climate conditions, e.g., by Murakami and his coworkers (Kim et al. 1997) [23].

The value for $Q_{f}$ given in Tables 1 and 2 is the maximum for a given land-use/landcover (LULC). This maximum is then scaled using a Fourier series to calculate hourly values of $\mathrm{Q}_{\mathrm{f}}$ for each LULC. In our mesoscale modeling, anthropogenic heat flux $\left(\mathrm{Q}_{\mathrm{f}}\right)$ is added to the sink/source term $\left(\mathrm{S}_{\theta}\right)$ of the potential temperature conservation equation for the first level of the model:

$$
\frac{\partial \theta}{\partial t}=V \cdot \nabla \theta^{*}+S_{\theta}
$$

The time-dependent anthropogenic heat flux is computed as:

Table 1: Some thermophysical properties assumed for urban Land-use and Land-cover (LULC). Based on [29]

\begin{tabular}{|l|l|l|l|l|}
\hline Urban LULC & $\alpha$ & Zo & Qf & $\eta$ \\
\hline Residential & 0.16 & 35 & 10.0 & 0.20 \\
\hline Commercia/Services & 0.14 & 150 & 10.0 & 0.05 \\
\hline Industrial & 0.20 & 35 & 10.0 & 0.05 \\
\hline Transp/Communic/Utilit. & 0.16 & 35 & 40.0 & 0.05 \\
\hline Indust/Commercial Complexes & 0.14 & 35 & 40.0 & 0.05 \\
\hline Mixed urban or built-up & 0.16 & 35 & 10.0 & 0.05 \\
\hline Other uiban/built up & 0.14 & 35 & 10.0 & 0.05 \\
\hline
\end{tabular}

In this table, $\alpha$ is albedo, $\mathrm{Zo}$ is roughness length $(\mathrm{cm}), \mathrm{Q}_{\mathrm{f}}$ is maximum anthropogenic heat flux $\left(\mathrm{W} / \mathrm{m}^{2}\right)$ for corresponding LULC, and $\eta$ is vegetation fraction.

Table 2: Thermophysical properties assumed for non-urban LULCs. Based on [29].

\begin{tabular}{|c|c|c|c|c|c|c|c|c|}
\hline Non-urban LULC & $\alpha$ & Zo & $\mathbf{s}$ & $\rho$ & $\mathrm{k}$ & $\mathrm{c}$ & $Q_{f}$ & $\eta$ \\
\hline Cropland/pasture & 0.18 & 12 & 0.30 & 1.8 & 0.0038 & 0.44 & 0.0 & 0.60 \\
\hline Orchards/groves & 0.1612 & 0.30 & 1.8 & 0.0038 & 0.44 & 0.0 & 0.60 & \\
\hline Confined feeding & 0.1212 & 0.30 & 1.8 & 0.0038 & 0.44 & 0.0 & 0.60 & \\
\hline Agricultural & 0.15 & 12 & 0.30 & 1.8 & 0.0038 & 0.44 & 0.0 & 0.60 \\
\hline Herbaceous rangeland & 0.185 & 0.03 & 1.6 & 0.0050 & 0.30 & 0.0 & 0.10 & \\
\hline Shrub/brush rangeland & 0.18 & 5 & 0.03 & 1.6 & 0.0050 & 0.30 & 0.0 & 0.10 \\
\hline Mixed raingeland & 0.18 & 5 & 0.03 & 1.6 & 0.0050 & 0,30 & 0.0 & 0.10 \\
\hline Deciduous forest & 0.15 & 350 & 0.20 & 1.8 & 0.0057 & 0.35 & 0.0 & $0.50:$ \\
\hline Evergreen forest & 0.18 & 350 & 0.20 & 1.8 & 0.0057 & 0.35 & 0.0 & 0.50 \\
\hline Mixed forest & 0.16 & $350^{\prime}$ & 0.20 & 1.8 & 0.0057 & 0.35 & 0.0 & 0.50 \\
\hline Streams/canals & 0.08 & 1 & 1.00 & 1.0 & 0.0015 & .1 .00 & 0.0 & 0.0 \\
\hline Lakes & 0.06 & 1 & 1.00 & 1.0 & 0.0015 & 1.00 & 0.0 & 0.0 \\
\hline Reservoirs & 0.08 & 1 & 1.00 & 1.0 & 0.0015 & 1.00 & 0.0 & 0.0 \\
\hline Bays/estuaries & 0.06 & 1 & 1.00 & 1.0 & 0.0015 & 1.00 & 0.0 & 0.0 \\
\hline Forested wetland & 0.16 & 0.001 & 0.50 & 1.5 & 0.0020 & 0.80 & 0.0 & 0.25 \\
\hline Nonforest wetland & 0.16 & 0.001 & 0.50 & 1.5 & 0.0020 & 0.80 & 0.0 & 0.25 \\
\hline Dry salt flats & 0.40 & 0.05 & 0.01 & 1.6 & 0.0050 & 0.30 & 0.0 & 0.0 \\
\hline Beaches & 0.40 & 0.05 & 0.01 & 1.6 & 0.0050 & 0.30 & 0.0 & 0.0 \\
\hline Sandy/non beach & 0.30 & 0.05 & 0.01 & 1.6 & 0.0050 & 0.30 & 0.0 & 0.0 \\
\hline Bare rock & 0.30 & 0.05 & 0.01 & 1.6 & 0.0050 & 0.30 & 0.0 & 0.0 \\
\hline Mines/quarries/pits & 0.25 & 0.05 & 0.01 & 1.6 & 0.0050 & 0.30 & 0.0 & 0.0 \\
\hline Transitional areas & 0.18 & 0.05 & 0.01 & 1.6 & 0.0050 & 0.30 & 0.0 & 0.0 \\
\hline Mixed barren land & 0.18 & 0.05 & 0.01 & 1.6 & 0.0050 & 0.30 & 0.0 & 0.0 \\
\hline Shrub/brush tundra & 0.18 & 10 & 0.05 & 13 & 0.0038 & 0.35 . & 0.0 & 0.20 \\
\hline Herbaceous tundra & 0.18 & 10 & 0.05 & 13 & 0.0038 & 0.35 & 0.0 & 0.20 \\
\hline Bare ground & 0.16 & 10 & 0.05 & 1.3 & 0.0038 & 0.35 & 0.0 & 0.20 \\
\hline Wet tundra & 0.20 & 10 & 0.05 & 13 & 0.0038 & 0.35 & 0.0 & 0.20 \\
\hline Mixed tundra & 0.19 & 10 & 0.05 & 1.3 & 0.0038 & 0.35 & 0.0 & 0.20 \\
\hline Peremnial snow & 0.80 & 0.005 & 0.20 & 0.8 & 0.0100 & 0.21 & 0.0 & 0.0 \\
\hline Glaciers & 0.35 & 0.005 & 0.20 & 0.8 & 0.0100 & 0.21 & 0.0 & 0.0 \\
\hline
\end{tabular}

In this table, $\alpha$ is albedo, $\mathrm{Zo}$ is roughness length $(\mathrm{cm}), \mathrm{s}$ is surface wetness, $\rho$ is density $\left(\mathrm{g} / \mathrm{cm}^{3}\right), \mathrm{k}$ is thermal diffusivity $\left(\mathrm{cm}^{2} / \mathrm{s}\right), \mathrm{c}$ is specific heat $(\mathrm{J} / \mathrm{g} \mathrm{K}), \mathrm{Of}$ is maximum anthropogenic heat flux $\left(\mathrm{W} / \mathrm{m}^{2}\right)$ for corresponding LULC, and $\eta$ is vegetation fraction. 


$$
Q_{f}(t)=Q_{\text {fmax }} \times F(t)
$$

where, $Q_{\text {fmax }}$ is a maximum heat flux and is a function of land use, and $F(t)$ is

$$
F(t)=A+* \sum_{n=1}^{3}\left[B_{n} \cos \left\{\frac{2 n \pi t}{24}\right\}+C_{n} \sin \left\{\frac{2 n \pi t}{24}\right\}\right]
$$

where $\mathrm{A}=0.557, \mathrm{~B} 1=-0.227, \mathrm{~B} 2=-0.006, \mathrm{~B} 3=-0.084, \mathrm{C} 1=-0.384, \mathrm{C} 2=0.016$, and $\mathrm{C} 3=-0.012$

A mesoscale model grid cell of area A $(5 \times 5 \mathrm{~km}$ in this study), consists of 625 subregions, each $-200 \mathrm{~m} \times 200 \mathrm{~m}$ (original USGS LULC grid cells). The average value of a parameter $P$ in area $A$ is then calculated to represent the subgrid variations in P. The simplest, and crudest, way to calculate this is through algebraic averaging:

$$
P=\frac{1}{A} \sum P_{i} A_{i}
$$

where $P_{i}$ is the value of a parameter in sub-area $A_{i}$ This method was used for all parameters except roughness length which was averaged based on the logarithmic wind profile equation:

$$
u(z)=\frac{u^{*}}{k} \ln \left(\frac{z-z_{d}}{Z_{o}}\right)
$$

where $\mathrm{u}^{*}$ is friction velocity, $\mathrm{k}$ is von Karman constant, $\mathrm{z}$ is height, $\mathrm{zd}$ is displacement height and $\mathrm{Zo}$ is roughness length. An averaging method suggested by Taha et al. [30] yields:

$$
Z_{o}=\Pi Z_{o i}{ }^{A_{i} / A}
$$

where Zoi is the roughness length of LULC (i) whose area is Ai and the symbol $\Pi$ denotes multiplicative averaging.

Once the base-case surface characteristics for the modeling domain are established, heat islands mitigation scenarios, i.e., increasing surface albedo and vegetation cover, are identified next.

\subsubsection{Albedo modifications}

One important surface-characteristics input to the meteorological model is surface albedo. For the purpose of this study, a gridded albedo database for the Los Angeles Basin was developed from satellite data of August 29, 1991. Albedo was derived from narrow-band data in the visible $(0.58-0.68 \mu \mathrm{m})$, near infrared $(0.725-1.1 \mu \mathrm{m})$, and middle infrared (3.55-3.93 $\mu \mathrm{m}$ ) following a method devised by Brest and Goward [31]. Albedo, thus calculated, ranges from a high of 0.22 in some parts of the Mojave desert to a low of 0.08 over the Pacific Ocean and mountain ranges. The average land albedo of the Los Angeles Basin was found to be 0.14 .

Theoretically, the albedo of an individual surface could be increased to up to 0.95 or even higher. Building and urban surface albedos on the order 0.80 have been measured in the field and albedos of over 0.95 have been measured in our laboratory[32]. However, for practical and visual environmental considerations, there is reason to believe that such a lange increase in albedo is difficult to achieve in urban settings and especially at lange scales. Also, except for heavily urbanized areas, e.g., Downtown, there is not much impervious surface area available for albedo modification. Thus, at the scale of a grid cell $(5 \times 5 \mathrm{~km})$, the maximum increase in albedo will probably never exceed 0.30 . Accordingty, a maximum albedo increase of 0.30 over existing values was deemed an extreme upper bound and used as such in this modeling work.

Within each $5 \times 5-\mathrm{km}$ cell, land use categories were sorted and their fractional aneas computed. We assumed that the albedo of certain land uses can be modified, e.g., residential areas, offices/commercial areas, and parking lots but albedos of others, such as parks, heavily vegetated areas, and deserts can not be changed. The method for computing various levels of increase in albedo is based on land-use/land-cover analysis. For this purpose, a 200-m-resolution land-use database (from the US Geological Survey) is analyzed and the amount of various surface types in each 200-m grid cell is estimated. Then, a certain level of albedo increase is assumed for each surface type, e.g., roofs, sidewalks, pavements, and parking lots. These increases are then averaged to 200-m resolution and then back to the resolution of the meteorological model. The increased albedo is computed from:

$$
\alpha_{i, j}^{\prime}=\alpha_{i, j}+\delta \alpha \sum_{L=1}^{n} f_{L_{i, j}}
$$

where $\alpha \mathrm{ij}$ is the original albedo of cell ( $\mathrm{i}, \mathrm{i}), \delta \alpha$ is a nominal (maximum) amount of increase in albedo (that could be achieved if a cell were $100 \%$ modifiable), and $f$ is the area fraction of modifiable land use " $\mathrm{L}$ " in cell (i,j). Two nominal albedo increases were simulated: a moderate increase $(\delta \alpha=+0.15)$ and a high increase $(\delta \alpha=+0.30)$. These levels correspond to increasing the average albedo of the entire land portion of the Los Angeles Basin modeling domain from a base-case value of 0.14 to 0.16 and 0.17 , respectively. For those grid cells whose albedo was increased, the average increase in albedo for the moderate case was 0.07 and for the extreme case, it was 0.13 . There were 394 cells (of 2158 land cells) whose albedo could potentially be modified (Figure 1).

\subsubsection{Vegetation cover modification}

The second heat island mitigation strategy involves increasing the amount of vegetative land cover. Additional trees planted in the basin would alter the meteorology through evapotranspiration and increased roughness. They also would alter the air quality through increased biogenic hydrocarton emissions, increased deposition of pollutants, and lowered air temperatures. All these effects are acoounted for in this modeling study.

The estimated current average vegetative cover in the Los Angeles Basin is $16 \%$. The estimated corresponding total biomass in the modeling domain is $-7 \mathrm{Tg}$ (teragrams). To estimate the possible levels of increase in vegetative cover, the fraction of each grid cell in the modeling domain that can be vegetated was identified based on land-use data. There were 394 cells (out of 2158 land cells) that could be candidates for tree planting (Figure 2). The increased tree cover in each modifiable cell was calculated from:

$$
\eta_{i, j}^{\prime}=\eta_{i, j}+\delta \eta \sum_{L=1}^{n} f_{L_{i, j}}
$$

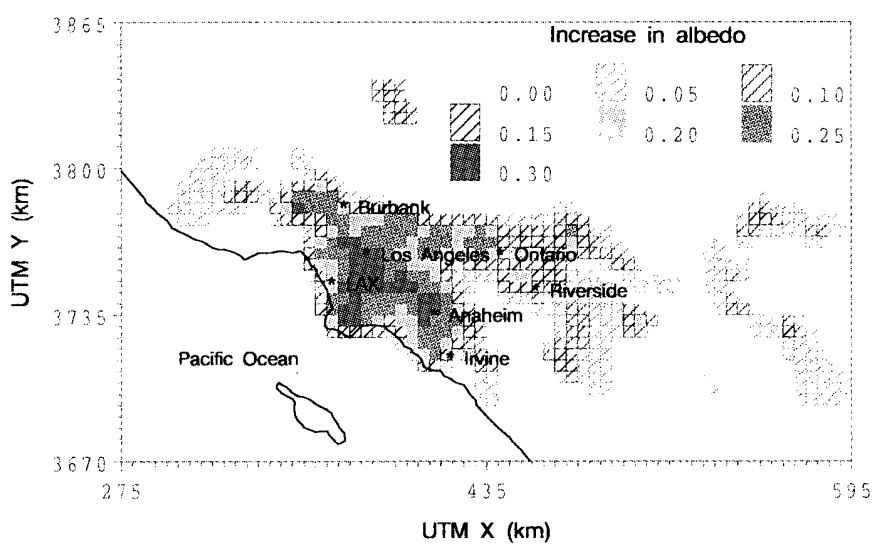

Figure 1 Area where albedo can be increased in the Los Angeles region. This is a high-increase scenario. The largest increase in central areas amounts to 0.30 
where $\eta^{\prime}$ and $\eta$ are the new and basecase vegetative covers in cell (ij) respectively, $\delta \eta$ is a nominal level of increase in vegetative cover (that would be achieved if a cell were $100 \%$ modifiable), and " $\mathrm{f}$ " is fractional area of bnd use category " $\mathrm{L}$ " in cell (ij). Two levels of possible vegetative cover increase were simulated: a moderate increase ( $\delta \eta=+0.15$ ) and a high increase $(\delta \eta=+0.30$ ) shown in Figure 2. These levels correspond to increasing the average tree cover in the basin from a base value of $16 \%$ to $17 \%$ and $18 \%$, respectively. In absolute numbers, the corresponding besin-wide total increases would be an additional -10 and 20 million trees, respectively. The latter, an extreme scenario, is simulated to establish an upper bound for the possible effects of increased vegetation in the Los Angeles Basin. The impact of increased vegetative cover in Japan would be different because Los Angeles is dry during peak summer conditions. Careful modeling would be necessary to understand the interaction of increased vegetation and air quality in Japan, where it is relatively more humid.

\section{MODELING ENERGY IMPLCATIONS}

\section{(SAVINGS IN AIR-CONDITIONING ELECTRICITY CONSUMPTION).}

The energy impacts of heat island mitigation were quantified with a building enengy simulation model [33]. These simulations also form the basis for modeling reduction in peak generation and emissions from power plants. In this model, albedo was increased from 0.25 to 0.55 on residential roofs and from 0.25 to 0.70 on office roofs. These changes are based on the levels of albedo increase demonstrated in the field [16]. On the other hand, the vegetation increase was modeled as an additional three trees per residential or commercial unit. The trees were "placed" on the south side of a building and each was modeled as a cube $7.5 \mathrm{~m}$ on the side, $7.5 \mathrm{~m}$ tall, with a summer transmissivity for solar radiation of 0.1 and a winter transmissivity of 0.9. Four prototypes were simulated with this model: one old and one new residential and one old and one new office buildings. A description and discussion of the development of these prototypes is provided in Konopacki et al. [34]. In this study, it is assumed that cooling is done with electricity while heating with gas.

Because the mesoscale meteorological model is typically nu for episodes of two to five days while the building energy model is typically run on an hourty basis for a whole year, it was necessary to create a full-year of hourty weather data (for energy simulations input) based on multi-episodic simulation results from meteorological model. A simple interpolative procedure was devised to modify an original Typical Meteorological Year (TMY) weather file for each region based on the differences between averaged simulated base and modified meteorological conditions. The procedure accounts for clear/overcast periods, time of day/night, air temperature, timelag effects, and other conditions, e.g, snow or rain. Taha et al. [35] explain this method in more detail.

To our knowledge, there have been no similar attempts in Japan to estimate the regional impacts on peak electrical demand of high-albedo surfaces and additional vegetation around homes. Other measures, such as high-albedo road surfaces, may also be effective.

\subsection{MODELING METEOROLOGICAL IMPLICATIONS}

To assess the impacts of cool cities on the regional climate of the Los Angeles Basin, a meteorological model was used. The meteorological impacts were simulated with the Colorado State University Mesoscale Model (CSUMM). The changes in meteorology, particularty air temperature, serve as basis for modeling the resulting impacts on air quality. The CSUMM is a hydrostatic, primitive-equation, three-dimensional Eulerian

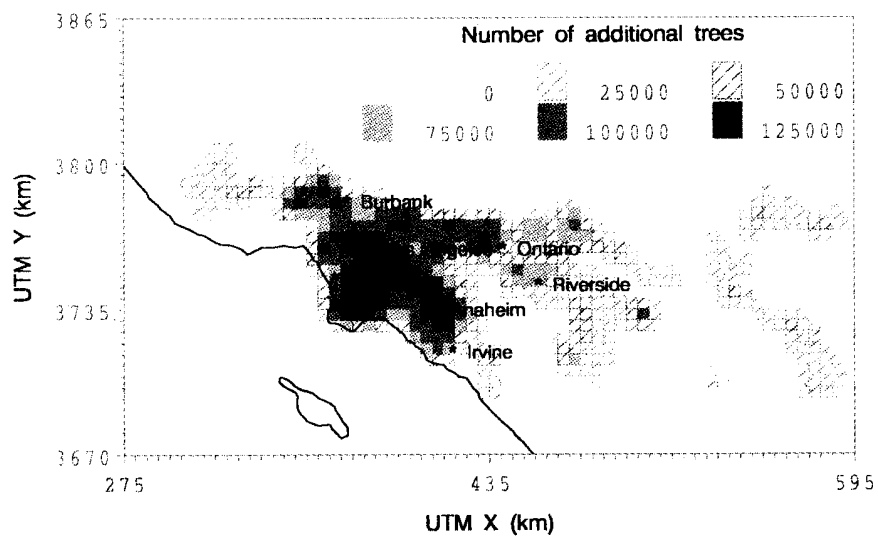

Figure 2 Area where vegetative fraction can be increased in the Los Angeles region. This is a high-increase scenario. The langest increase in central areas amounts to an additional 125,000 trees per $25 \mathrm{~km}^{2}$ grid cell.

model [36]. The model is incompressible, and employs a $\sigma \mathrm{z}$ coondinate system. It uses a first order closure scheme in treating sub-grid scale terms of the governing differential equations:

$$
\begin{aligned}
& \frac{\partial \rho}{\partial t}=-\nabla \cdot \rho V \\
& \frac{\partial \theta}{\partial t}=-V \cdot \nabla \theta+S_{\theta} \\
& \frac{\partial V}{\partial t}=-V \cdot \nabla V-\frac{1}{\rho} \nabla p-g k-2 \Omega \times V \\
& \frac{\partial q}{\partial t}=-V \cdot \nabla q+S_{q}
\end{aligned}
$$

In equations $9-12, \rho$ is density, $\mathrm{V}$ is the wind velocity vector, $\theta$ is potential temperature, $S \theta$ is sink/source term for potential temperature, $p$ is pressure, $g$ is gravitational acceleration, $\mathrm{k}$ is unit vector in the z-direction, $\Omega$ is angular velocity of the earth, q specific humidity, and Sq is source/sink term for specific humidity.

The model's domain is about $10 \mathrm{~km}$ high with an undertying soil layer about $50 \mathrm{~cm}$ deep. In this study, 22 atmospheric computational levels were used. The CSUMM generates time-dependent, three-dimensional fields of prognostic variables as well as a mixing height field that can be used as input to an air quality (e.g, photochemical) model.

\subsection{MODELING AIR QUALTY IMPUCATIONS}

The air quality impacts of cool cities were simulated with the Urban Airshed Model (UAM). The UAM is a three-dimensional, Eulerian, photochemical model capable of treating inert and chemically-reactive atmospheric pollutants. It has been recommended by the US EPA for ozone air quality modeling studies of urban areas [37]. The UAM simulates the advection, diffusion, transformation, emission, and deposition of pollutants:

$$
\frac{\partial c_{i}}{\partial t}+\nabla \cdot\left(V c_{i}\right)=\nabla \cdot\left(K \nabla c_{i}\right)+R_{i}+S_{i}+D_{i}
$$

In equation 13 , ci is the concentration of species " $i ", K$ is the turbulent diffusion coefficient, and $\mathrm{R}, \mathrm{S}$, and $\mathrm{D}$ are the reaction, source, and sink (deposition) terms for species "i".

The UAM treats about 30 chemical species and uses the carbon bond CB-IV mechanism [38]. It acoounts for emissions from area and point sources, elevated stacks, mobile and stationary sources, and vegetation (biogenic emissions). In this study, the UAM was run with 5 atmospheric layers of variable depth and the top of the domain was set at $2100 \mathrm{~m}$ for the Los Angeles Basin. 


\section{IMPLICATIONS OF HEAT ISLANDS MITIGATION.}

The models described in section 2 were used in combination to simulate the impacts of urban heat island mitigation on meteorology, energy, and air quality. In this section, we discuss some of these simulated impacts.

\subsection{IMPACTS ON METEOROLOGY}

While many meteorological impacts result from changing surface albedo, the most important impact is seen in the temperature field. The simulations suggest that a decrease of up to ${ }^{\circ} \mathrm{C}$ in air temperatures may be possible with moderate increases in albedo. In this case, most of the temperature depression occurs in the central Los Angeles Basin, with changes of about $1^{\circ} \mathrm{C}$ in surrounding areas (Figure 3). With lange increases in albedo, simulated reductions of up to $4.5^{\circ} \mathrm{C}$ occur in the central basin, with an average decrease of $2{ }^{\circ} \mathrm{C}$ in surrounding areas.

The impacts of lowered air temperatures on biogenic hydrocarbon emissions from vegetation in the Los Angeles Basin were calculated. The correction of isoprene and monoterpenes emission for solar radiation and domain-varying temperature was carried out using an environmental algorithm [12]. The corrections were performed for each hour and each grid cell using output from the CSUMM mesoscale simulations of that episode. The decrease in biogenic hydrocarbon emissions as a result of increasing the albedo was found to be 7 metric tons per day (mtpd) or about $2 \%$ for the moderate albedo increase and $13 \mathrm{mtpd}(3.5 \%)$ for the high albedo increase. Although these reductions are small, they are nevertheless acoounted for in the photochemical simulations discussed in this paper.

On the other hand, increasing the vegetative cover affects the wind, atmospheric moisture, and temperature fields, particularty in the lowest layers of the atmosphere. Wind is modified because surface roughness changes as additional areas are vegetated, whereas atmospheric moisture and air temperature are affected because of the increased evapotranspiration from additional vegetation. The changes in surface albedo, brought on by increased vegetation also affect the temperature field. The changes in temperature because of albedo and evapotranspiration modifications in turn affect the wind field. All of these effects are accounted for in this modeling study.

For the study episode, a moderate vegetation increase case in the Los Angeles Basin could be up to $2{ }^{\circ} \mathrm{C}$ cooler at $3 \mathrm{pm}$ (on August 27) compered to the simulated basecase conditions. In the high vegetation increase case (Figure 4), decreases of up to $3.5^{\circ} \mathrm{C}$ in the west basin and an average $1.5{ }^{\circ} \mathrm{C}$ in surrounding areas may be possible.

\subsection{IMPACTS ON AIR QUALTTY}

In this section, we discuss the impacts of increased albedo and increased vegetative

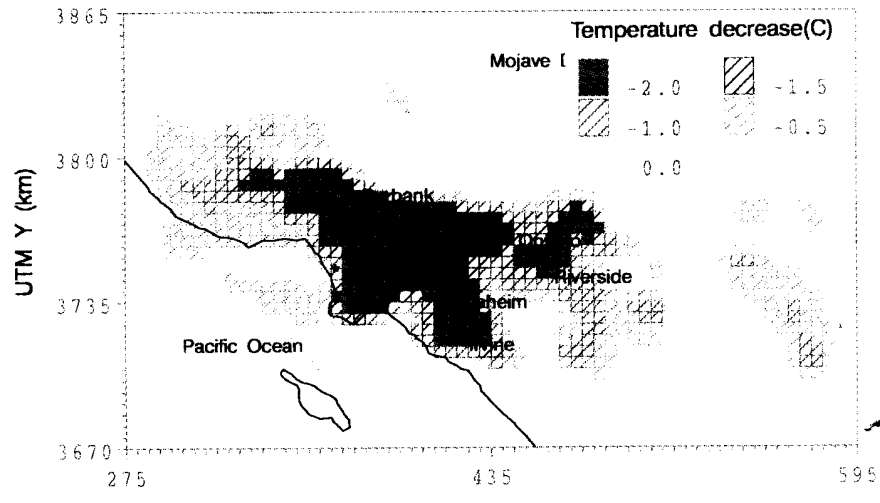

UTM $X(\mathrm{~km})$

Figure 3 Decrease in air temperature at $3 \mathrm{pm}$ on a late-August day as a result of moderate increases in urban albedo.

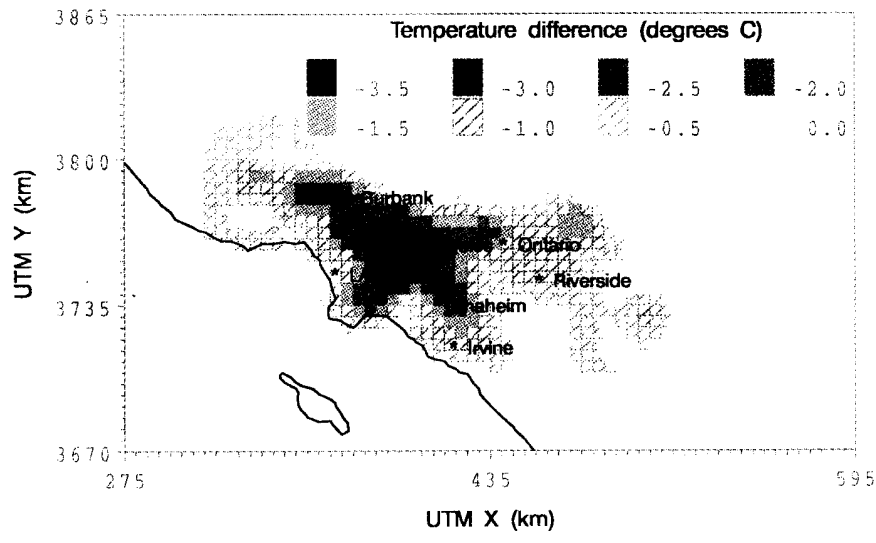

Figure 4 Decrease in air temperature at $3 \mathrm{pm}$ on a late-August day as a result of lange increases in vegetative fraction.

cover on air quality. This is a culmination of all previous modeling steps, i.e., meteorology, energy, and air emissions.

For reference, Figure 5 shows the simulated base-case ozone concentrations field (in $\mathrm{ppb}$, at $3 \mathrm{pm}$ on August 27). Concentrations on the order of $200 \mathrm{ppb}$ are found in several areas in the Basin. There are 385 grid cells in the modeling domain with ozone concentrations over $120 \mathrm{ppb}$ (the federal ozone standand) and 1360 cells over the Califomia standard of $90 \mathrm{ppb}$ during this peak hour.

\subsubsection{ALBEDO IMPACTS}

When albedo is increased and temperature drops, a decrease in ozone concentrations is generally expected. The main mechanism through which air temperature affects ozone is believed to be the chemistry of peroxyactyl nitrate. However, when albedo is increased, it is not only temperature that decreases but also the depth of the mixed layer at some bcations. This can potentially increase the concentrations. Decreasing nearsurface temperatures may also recuce the strength of the sea-breeze circulation by a small amount (less than $1 \mathrm{~m} / \mathrm{s}$ ). Thus, both increases and decreases in ozone concentrations can be expected depending on location-specific meteorological conditions and emissions. Additionally, when ozone is prevented from forming in one area (because of lower air temperatures), its precursors can still be transported downwind or recirculated to an upwind bcation where they can cause a local increase or decrease in ozone.

It is worth mentioning here that many high-albedo materials are poor reflectors in the ultra-violet (UV) range up to about $0.4 \mu \mathrm{m}$. Thus increasing the albedo of an urban area by properly selecting high-albedo materials should not affect the rate of NO2 photolysis and the potential for ozone formation will not increase. For example, nitrogen dioxide's quantum yield for photodissociation drops to near zero at wavelengths greater than $0.4 \mu \mathrm{m}$ [39].

Figure 6 shows the difference in ozone concentrations (ppb) from the base-case (at 3 pm on August 27) for a case with lange increase in albedo. There are increases and decreases but the magnitude of the decreases in concentrations is generally langer than that of the increases and the net basin-wide effect is a reduction in ozone mass. The langest decreases in ozone are on the order of $40 \mathrm{ppb}$ whereas the langest increases are on the order of $20 \mathrm{ppb}$. At $3 \mathrm{pm}$, there are 640 metric tons $(4.7 \%)$ less ozone in the mixed layer due to large increases in albedo.

To provide a more relevant evaluation of the potential air quality impacts of extensively using high-albedo materials, a simple exposure analysis is discussed in this section. We can define population-weighted exceedance exposure (PE) as: 


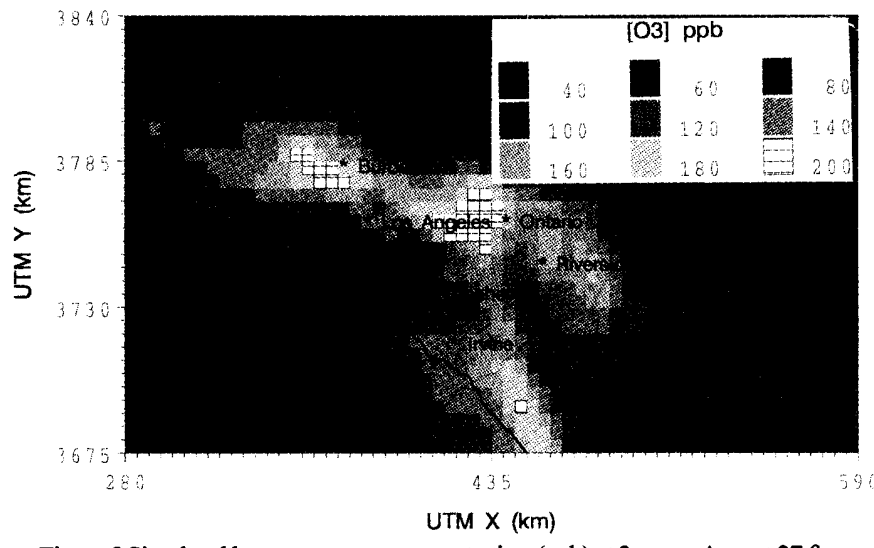

Figure 5 Simulated base-case ozone concentrations(ppb) at 3pm on August 27 for the Los Angeles Basin

$$
P E=\frac{\sum_{x=1}^{X} \sum_{h=1}^{H} P_{(x)}\left[C_{(i, x, h)}-C_{t}\right] H_{(\Delta C)}}{\sum_{x=1}^{X} \sum_{h=1}^{H} P_{(x)} C b_{(x, h)}}
$$

where $\mathrm{x}$ is grid-oell identifier (location), $\mathrm{h}$ is hour identifier (time), $\mathrm{P}$ is population in grid cell ( $\mathrm{x}), \mathrm{C}_{(\mathrm{y} x \mathrm{~h})}$ is ozone concentration (ppb) in cell ( $\mathrm{x}$ ) at hour (h) for case (i), $\mathrm{C}_{\mathrm{t}}$ is a reference threshold concentration, $\mathrm{H}$ is the Heavyside function which is equal to $\mathrm{l}$ if concentrations are in the range given by $\Delta \mathrm{C}$, that is when $\mathrm{C}_{(\mathrm{i} \times \mathrm{h})}>\mathrm{C}_{(\mathrm{p})}$ and 0 otherwise (when $\mathrm{C}_{(\mathrm{x} x \mathrm{~h})} \ll \mathrm{C}_{(\mathrm{p})}$ and $\mathrm{Cb}_{(\mathrm{x}) \mathrm{h})}$ is base-case total ozone concentration in cell $(\mathrm{x})$ at hour (h). Two thresholds (C) are considered: 1) $90 \mathrm{ppb}$ (Califomia Ambient Air Quality Standard, CAAQS), and 2) 120 ppb (National Ambient Air Quality Standard, NAAQS)

In the simulated base-case conditions, $34 \%$ of the basin-wide population-weighted exposure at $3 \mathrm{pm}$ is over the CAAQS but is only $32 \%$ and $30 \%$ in the moderate and lange albedo increases, respectively (Table 3). In terms of the NAAQS, the base-case conditions exhibit $18 \%$ exposure over the standard. In the moderate and extreme albedo increases, exposure drops to $16 \%$ and $15 \%$, respectively. The basin-wide net effects of increasing albedo seem to be significant, keeping in mind the severity of this episode.

\subsection{VEGETATION IMPACTS}

In terms of ozone air quality, the UAM simulations suggest that planting low-emitting trees would cool the air (thus slow the photochemical reactions), scavenge pollutants, and decrease biogenic emissions from other (existing) vegetation without introducing

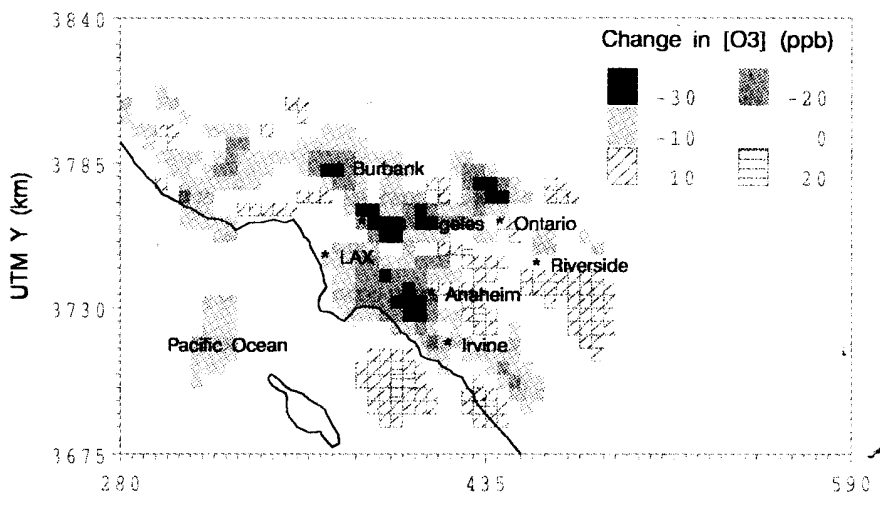

UTM $\times(\mathrm{km})$

Figure 6 Difference in ozone concentrations from the base case at $3 \mathrm{pm}$ on August 27. This case with large increases in albedo
Table 3. Population-weighted exceedance exposure to ozone at 3 pm on August 27.

\begin{tabular}{|l|rc|}
\hline Couse & CAAOS & $>$ NAAQS \\
\hline Base & $34 \%$ & $18 \%$ \\
Moderne albedo increase & $32 \%$ & $16 \%$ \\
Large albedo increase & $30 \%$ & $15 \%$ \\
\hline
\end{tabular}

CAAQS: Califomia Ambient Air Quality Standand ( $90 \mathrm{ppbO}_{3}$ )

NAAQS: National Ambient Air Quality Standard (120 ppb $\mathrm{O}_{3}$ )

Table 4. Population-weighted percent exceedance exposure to ozone at $3 \mathrm{pm}$ on August 27.

\begin{tabular}{|l|ll|}
\hline Crse (D) & CAAOS & $>$ NAAOS \\
\hline Basecose & $34 \%$ & $18 \%$ \\
Modernte increase, low emitters & $32 \%$ & $16 \%$ \\
High increase, low emitters & $29 \%$ & $14 \%$ \\
\hline
\end{tabular}

significant additional hydrocarbon emissions. There exists a number of tree species that emit very small, sometimes undetectable amounts of hydrocarbons. Elm, Crape myrtle, Cedar, and Judas trees are a few examples of species that emit less than $1 \mu \mathrm{g} / \mathrm{g} \mathrm{hr}$ of these compounds [40]. Figure 7 shows a case in which high increases in low-emitting vegetation were simulated. The concentration differences from the basecase are shown for $3 \mathrm{pm}$ on August 27. There ane more cells with lowered ozone concentrations than cells with increased concentrations. In addition, the magnitude of the decrease is langer than the magnitude of the increase and the result is a net decrease in ozone.

UAM sensitivity simulations of this episode suggest that tres emitting roughly more than $2 \mu \mathrm{g} / \mathrm{g} \mathrm{hr}$ of isoprene and $1 \mu \mathrm{g} / \mathrm{g}$ hr of monoterpenes, if introcuced in the Los Angeles Basin, would significantly increase ozone formation. Of course, examination of other episodes and meteorological conditions may render this conclusion more or less valid.

To evaluate the impacts of increased vegetation cover on air quality, changes in exposure to ozone are examined using the definition previously given in Equation (14). Table 4 summarize simulated percent excedance exposure above two thresholds during the hour of 3 pm on August 27.

At that peak smog hour, the simulated percent population-weighted exceedance exposure to ozone above the California Ambient Air Quality Standard (CAAQS) for the moderate and high vegetation-increase cases is $5 \%$ and $14 \%$ lower than in the basecase, respectively. Percent exceedance exposure above the National Ambient Air Quality Standard (NAAQS) is decreased by $11 \%$ and $22 \%$, respectively.

Together, increasing albedo and vegetation fraction (cool cities) can reduce the production of smog with associated savings of $\$ 360$ million per year for the Los Angeles Basin. These are savings in avoided health costs and missed work hours [41].

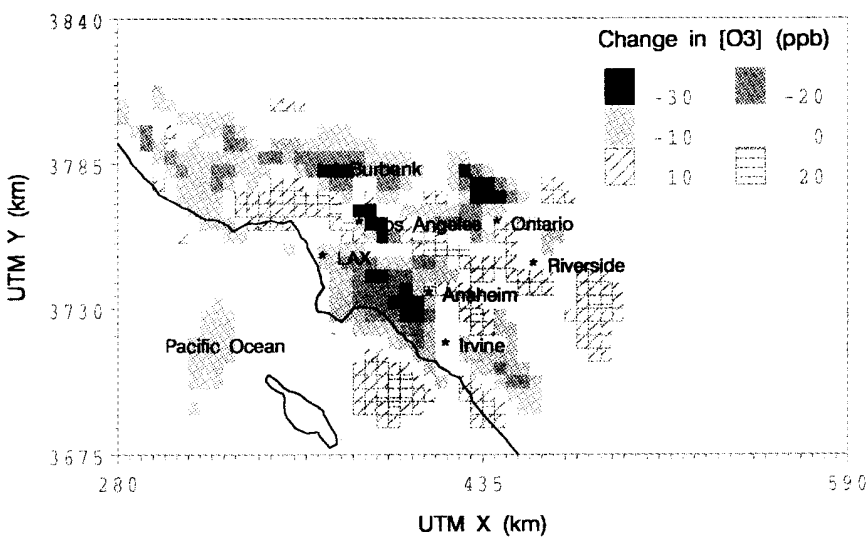

Figure 7 Difference in ozone concentrations from the simulated basecase at 3pm on August 27. This case shown corresponds to high increase in low-emitting vegetation 


\section{CONCLUSIONS AND FUTURE DIRECTIONS}

Urban heat islands can have both environmental and energy implications. They can increase air emissions and, thus, exacerbate air pollution problems. They can also significantly increase cooling loads in summer, especially in the mid- and low-latitudes. This paper reviewed our research at Lawrence Berkeley National Laboratory targeting the reduction or complete mitigation of urban heat islands and their unwanted effects. This paper has focussed on the Los Angeles region, but the approach is suitable for other regions throughout the world.

It is technically feasible to mitigate urban heat islands. Two very simple and effective methods for mitigation are 1). increasing surface albedo of paving and roofing materials and 2). increasing vegetation cover. While it appears to be economically feasible to mitigate urban heat islands, the strategies to follow may differ from one location to another. In dry climates, increased surface albedo and increased vegetation cover may be equally effective, whereas in humid climates, urban reforestation may not be a good strategy because the humid air does not promote evapotranspiration from soil-vegetation systems. Thus in humid climates like Japan, increased urban albedo may be the strategy of choice. More research is needed in the area of urban heat island mitigation. Both numerical modeling and field-measurements are necessary.

\section{ACKNOWLEDGEMENTS}

This paper summarizes some aspects of our research since 1985 in the Heat Island Group at the Lawrence Berkeley National Laboratory. This work was funded by the U.S. Department of Energy under contract DE-AC03-76SF00098. Thanks are also extended to JSPS who provided a short-term fund to support this collaborative research. The Mitsubishi Foundation gave a support for publishing this paper too.

\section{REFERENCES}

[1] Changnon, S.A. Jr., 1976. Inadvertent weather modifications. Water Resources Bulletin, vol. 12 , 695-718.

[2] Changnon, S.A Jr, 1981. METROMEX: A review and summary. Meteorological Monographs, Vol 18, No. 40. American Meteorological Society

[3] Chandler, T.J, 1960. Wind as a factor of utban temperatures: A survey in North-East London. Weather, Vol. 15, No. 6, 204-213.

[4] Oke, TR., 1988. The urban energy balance. Progress in Physical Geography, Vol. 12 №. 4, 471-508.

[5] Oka, Tatsou, 1980. Thermal enviromment in urben areas. Report D7:1980, Swedish Council for Building Research, Stockholm, Sweden.

[6] Hosler, C.L. and Landsberg HE., 1977. The effect of localized man-made heat and moisture sources in mesoscale weather modification. In Energy and Climate, National Academy of Sciences, Washington, D.C.

[7] Dabberd, WF. and Davis, PA, 1978. Determination of energetic characteristics of urben-ural surfaces in the Greater St Louis area Boundary-Layer Meteorology, Vol. 14, 105-121.

[8] Oguntoyinbo, J.S., 1986. Some aspects of the urban climates of tropical Africa Procedings of the Conference on Urban Climatology and its Application With Special Regards to Tropical Areas. WMO, Geneva, Switzerland

[9] Landsberg $\mathrm{H}$, 1981. The Uiban Climate, Academic Press, New York

[10] Goodridge, J. 1987. "Population and temperature trends in Catifomia", Proceedings of the Pacific Climate Workshop, Pacific Grove, California, March 22-26, 1987

[11] Taha, H, Konopacki, S., and Akberi, H. 1997. "Impacts of lowered urban air temperatures on precursor emission and ozone air quality", Accepted for publication in The Journal of the Air \& Waste Management Association

[12] Guemher, A; Zimmerman, P; Harley, P; Monson, R; and Fall, R. "Isoprene and monoterpene emission rate variability. Model evaluations and sensitivity analysis", Joumal of Geophysical Research, Vol 98, №. D7 (1993)pp. 12609-17.

[13] Taha H., Douglas, S., and Haney, J. 1997. "Mesoscale meteorological and air quality impacts of increased urban albedo and vegetation", Energy \& Buildings - Special Issue on Uitban Heat Islands, Vohume 25, Number 2(1997), pp. 169-177.

[14] Taha H. 1997. "Modeling the Impacts of Large-Scale Albedo Changes on Ozone Air Quality in the South Coast Air Basin", Atmospheric Environment, Vol. 31, No. 11, pp. 1667-1676 (1997).

[15] Taha, H. 1996. "Modeling the Impacts of Increased Uiban Vegetation on the Ozone Air Quality in the South Coast Air Basin", Atmospheric Environment, Vol. 30, №. 20 (199\%), pp. 34233430.

[16] Akbari, H, Bretz, S., Kum, D., and Hanford, J. 1997. "Peak power and cooling energy savings of high-albedo roofs". Energy \& Buildings, Volume 25, №. 2, (1997), pp. 117-126.

[17] Parker, D.S. and Barkaszi, S.F. 1997. "Roof solar reflectance and cooling energy use: Field research results from Florida". Energy \& Buildings, Volume 25, No. 2, (1997), pp. 105-115.

[18] Simpsan, JR and McPherson, E.G. 1997. "The effects of roof albedo modification on cooling loads of scale model residences in Tueson, Arizona". Energy \& Buildings, Volume 25, №. 2 (1997) pp. 127-137.

[19] Taha, H., Akbari, H. and Rosenfeld, A. (1988) Residential cooling loads and the urban heat island: The effects of albedo. Building and Environment, Vol. 23, No. 4, po. 271-283.
[20] Taha H. 1995. "Urban Climates and Heat Islands: Albedo, Evapotranspiration, and Anthropogenic Heat", Energy \& Buildings - Special lssue on Urban Heat Islands, Volume 25, Number 2(1997), pp. 99-103.

[21] Sailor, D. 1993. "Role of surface characteristics in urban meteorology and air quality", PhD. dissertation. University of Califomia - Berkeley.

[22] Gabersek, S. and Taha $H$. "Impacts of surface characteristics changes on urban heat island intensity". ICB 96, 14th Intemational Congress of Biometoorology, September 1-8, 19\%, Ljubljana, Slovenia

[23] Kim, S., Murakami S., Mochida A., and Ooka R. 1997. "CFD analysis of urban heat island in Tokyo: Effect of land-use conditions on urtan climate", Procoedings of the 7th International Conference on Computing in Civil and Building Engineering", 19-21 August 1997, Seoul, Korea

[24]Ojima, T., Murakami, S., and Sugiyama, H. 1995. "Eoological city simulations of Tokyo Metropolitan Area", Tectmical Report No. 95-36, Advanced Research Center for Science and Engineering Waseda University.

[25]Gao, W., Sugiyama, H., and Ojima, T. 1995. "Field study of effect of street and its on thermal environment of sidewalks", J. Archit Plann. Environ. Eng, AIJ, No. 469, pp. 53-64 (March 1995).

[26]Gao, W., Miura, S., and Ojima, T., 1994. "Site survey on formation of thermal cool island due to park and inner river in Kotołu, Tokyo", J. Anchit. Plann. Environ Eng, ALJ, No. 456, pp. 75-83 (Febnary 1994)

[27] Lii, X. 1994. "Estimating surface albedo using AVHRR satellite imagery", Chapter 3 in "Analysis of Energy Efficiency and Air Quality in the SoCAB - Phase II Pre-Final Report", by H Taha et al, LBL Report No. 35728

[28] Horie, Y. Sidawi, S., Ellefsen, R. 1990. "Imventory of leaf biomass and emission factors for vegetation in Califomia's South Coast Air Basin", Final Report, Contract No. 90163, South Coast Air Quality Management District, Diamond Bar, Califomia

[29] Pielke, R 1984. "Mesoscale Meteorological Modeling" , Academic Press.

[30] Taha, H, Landsfeld, M., Ritschard, R, Akbari, H, Winer, A, and Huang B., 1993. "Surface characterization of the South Coast Air Basin: Albedo, surface moisture, and roughness length", in Lawrence Berkeley National Laboratory Report 33051, Berkeley, California, pp. 201-234.

[31] Brest, C.L. and Goward, S.N. 1987. "Deriving surface albedo from namow band satellite data", Intermational Joumal of Remote Sensing 8:351-367.

[32]Berdahl, P. and Bret, S.E. 1997. "Preliminary survey of the solar reflectance of cool roofing materials", Energy and Buildings - Special Issue on Uiban Heat Islands and Cool Commmities, Vol. 25, No. 2(1997), pp. 149-158.

[33] Building Energy Simulation Group (BESG), "Overview of the DOE-2 Building Energy Analysis Program, Version 2.1D," Lawrence Berkeley Laboratory Report LBL-19735, 1990, Berkeley, Califomia

[34] Konopacki, S., Akbari, H, Gabersek, S., Gartland L, Moezzi, M and Pomerantz, M "Energy and Cost Benefits from Light-Colored Roofs in 11 U.S. Cities", Lawrence Berkeley National Laboratory LBL-39433, 1996, Berketey, Califomia

[35] Taha, H, Konopacki, S., and Gabersek, S. 1996. "Impacts of large-scale surface modifications on meteorological conditions and energy use: A 10-region modeling study", Submitted to Theoretical and Applied Climatology.

[36] Pielke, R. 1974. "A three-dimensional numerical model of the sea breeze over South Florida", Monthly Weather Review, 102:115-139.

[37] US EPA 1986. "Guideline on Air Quality Models (Revised)". U.S. Environmental Protection Agency EPA-450/2-78-027R

[38] Gery, M.W., Whitten, G.Z., Killus, JP. 1988. "Development and testing of the CBM-IV for urban and regional modeling", Report EPA-6003-88-012 U.S. EPA, Research Triangle Park, NC

[39] Harker, A.B., Ho, W., and Ratto, J.J. 1977. "Photodissociation quantum yield of NO2 in the region 375-420 nm", Chem. Phys. Lett, Vol.50, pp. 394-397 (1977).

[40] Benjamin, M.T., Sudol, M, Bloch, L. and Winer, A. 1996. "Low emitting urban forests: A taxonomic methodology for assigning isoprene and monoterpene emission rates", Atmospheric Environment, Vol. 30, No. 9, pp. 1437-1452(1996).

[41] Rosenfeld, A., Romm, J., Akbari, H., Pomerantz, M., Taha H. 1996. "Policies to rechice heat islands: Magnitudes of benefits and incentives to achieve them", Lawrence Berketey National Laboratory Report No. LBL-38679 UC-1600, Berkeley, Califomia

\section{和文要的}

\section{1. 檘要}

都市のヒートアイランド現象は過去の 50 年の間よく研究されてきた。例 えばカリフォルニアではピーク都市気温は 100 年あたり約 $0.4^{\circ} \mathrm{C}$ 上がってい る。ロサンゼルスでは、年間最高気温は 1940 年以来約 $4^{\circ} \mathrm{C}$ 增大する。日本 では、関西と関東領域の都市ヒートアイランドが出現し、最近の数 10 年の 間に強度が増大している。

気温の上昇とともに、人工的、または生物的 VOC の発散が増加する。大 気の光化学反心は温度の増加によって加速する。ロサンゼルスでの実測では、 気温は $23^{\circ} \mathrm{C} よ り$ 低い場合には、オゾンの濃度は国家基淮を超えないが、気 温はそれ以上になると、オゾンの濃度は基準を大きく上可る。

従って、ヒートアイランドの緩和が求められている。本文では、都市被覆 面の改善及ひ化の両面から、都市のヒートアイランドを和らげる意義や可 能性について私達のアプローチとシミュレーション方法を検討する。特に、 アメリカと世界の最も大きく、最もスモッグが多い都市領域のうちの 1 つ、 
ロサンゼルス盆地を例にして、エネルギー、気象および光化学の (空気品質) シミュレーションの結果を述べる。

\section{2. 研究方法}

本研究では、ヒートアイラント緩和の効果を把握するため、メソスケール気 象モデルーColorado 州立大学メソスケールモデル (CSUMM) 一を用いた。 式 9-12 に示すように、CSUMM は静的に、基磷的な方程式で、3 次元オイ ラ一非缩性モデルである。

気温の大気質への影響は “都市気流域モデル”（UAM）を用いた。UAM は 3 次元、オイラー、光化学モデルで、大気污染物の化学反忘等を扱うこと ができる。都市エリアにおけるオゾン大気環境の評価をするとき、このモデ ルはアメリカの檪境保護局（EPA）により推蔦されている。UAM は污染物 の移流、抎散、変化、発散、付着等をシミュレーションし、基本式は式 13 に示す。

気象モデルに入力する土地利用データはアメリカ地理院（USGS）のデー 夕及ひ衛星のデータによるものである。その属性は表 1 と表 2 に示寸。表に 示す人工排熱 $\mathrm{Q}_{\mathrm{f}}$ は特定の土地利用や被㫏面(LULC)に対する最大值である。 時刻の変化はフーリエ級数（式 3）で求める。また、人工排熱はエネルギー 方程式の熱源項として扱う (式 1)。

計算エリアは図 1 に示すように、ロサンゼルス盆地の $195 \mathrm{~km} \times 320 \mathrm{~km}$ で、 メッシュサイズは $5 \times 5 \mathrm{~km}$ である。高さ方向では上空まで約 $10 \mathrm{~km}$ 、地中ま で約 $50 \mathrm{~cm}$ 樑さで、メッシュ数は 22 とした。また、地中の土翼湿度は $0.05 、$ 比重は $1.6 \mathrm{~g} / \mathrm{cm}^{3}$ 、熱拡散係数は $0.0033 \mathrm{~cm}^{2} / \mathrm{s}$ 、比熱は $1.26 \mathrm{~J} / \mathrm{gk}$ 。メッシュごと の平均特性は式 4 を用いて計算する。

\section{地表面反射絝の改善}

ヒートアイランドを緩和するための方法として都市の反射率をあげること が考えられ、地表面反射率はこの研究での重要な要素となる。ロサンゼルス 盆地で、1991 年 8 月 29 日の人工衛星データを利用して、反射率のデーダ 一スを作った。結果として、Mojava 砂莫のある部分は反射率 0.22 の高い值 から太平洋や山等に 0.08 の低、值まで变化するが、ロサンゼルス盆地の平均 值は 0.14 であった。理論上では、表面の反射率は 0.95 またその以上増加で きるが、 $5 \times 5 \mathrm{~km}$ のスケールを考える時、実際ではメッシュ平均の反射率は 通常 0.3 を超えない。メッシュごとの反射率は式 7 によって計算する。本研 究では、二つケース：中増加 $\delta \alpha=+0.15$; 高増加 $\delta \alpha=+0.3$ を設定した。

\section{緑技䒠の增加}

ヒートアイランドを緩和するもう一つ方法として、緑被率を増加させるこ とである。樹木の蒸発熱によって気候を変化させる。また、樹木は同時に二 酸化炭素の吸収、酸素の排出、污染物の吸収、気温の低减等によって、大気 質を改善することができる。

本研究では、それらの影響も考慮している。可能な緑被率の増加を二ケー ス、即ち、中増加 $\delta \eta=+0.15$; 高増加 $\delta \eta=+0.3$ を設定した。

\section{3. ヒートアイランド悢和の效果}

\section{1 気候人の颢需}

表面反射率の最も重要なインパクトは気温への影響である。表面反射㳯の 中増加ヶースでは、シミュレーションによると、約 $2{ }^{\circ} \mathrm{C}$ 気温低减ができる

(図 3)。表面反射率の高増加ケースでは、ロサンゼルス盆地の中心部にお ける気温は約 $4.5^{\circ} \mathrm{C}$ 低减が見られ、周辺の気温は平均で $2^{\circ} \mathrm{C}$ 减少が生じる。

緑地の増加は大気の風・湿度・熱環境一大きな影響を与える。緑被率の中 増加ケースでは、8月 27 日の午後 3 時に通常ケースより約 $2^{\circ} \mathrm{C}$ 気温低减が 見られた。た、高増加ケースではロサンゼルス盆地の西エリアで気温が約 $3.5^{\circ} \mathrm{C}$ 减少している。周辺エリアも平均約 $1.5^{\circ} \mathrm{C}$ 気温減少ができる。

\section{2 大氛賽への影慗}

この節では、反射率や緑被率の増加による大気質への影響を検討する。参 考として、図5にはシミュレーションのベースケースのオゾン濃度 (8月 27 日午後 3 時):を示す。ロサンゼルス盆地の相当部分では、オゾン濃度は $200 \mathrm{ppb}$ を超え、カリフォルニアの 90ppb 基淮を大きく上まわっている。

\section{2.1 反射爽の影震}

反射率の増吅や気温の低减のよってオゾン濃度に対する低減が大きく期待 される。図 6 では、反射率の高増加ケースがベースケースと比較したオゾン 濃度の変化を示している。オソンの减少の最大値は約 40ppb であるが、增 加の最大值は約 $20 \mathrm{ppb}$ になっている。午後 3 時ころ、反射率の増加による オゾンの减少は約 640Mton (4.7\%) になっている。高反射率材料の大気質 への影響をより相対的に評価するため、簡易な”露出”分析を行った。地域 人口当たりオソンに対する露出超過量を式 14 のように定義した。 P はメッ シュセル $(\mathrm{x})$ の人口、 $\mathrm{C}_{(\mathrm{x} x \mathrm{~h})}$ はケース I メッシュ $\mathrm{x}$ の時刻 $\mathrm{h}$ 時のオゾン濃度、 $\mathrm{C}_{\mathrm{l}}$ は基淮限界濃度、はメッシュ $\mathrm{x}$ の現状総オゾン濃度である。基潅艮界濃度に は一つの基淮がある。一はカリフォルニア大気噮境質量基準 90ppb、もう 一つは国家大気罢境質量基淮 $120 \mathrm{ppb}$ である。

現状ケースでは，地域人口当たりオゾンに対する露出量の $34 \%$ はカリフ オルニア大気環境質量基淮を超えるのに対して、反射率の中増加及ひ高堌加 ケースではそれぞれ 32\%及び 30\%となっている（表 3)。国家基淮の場合、 現状ケースでは $18 \%$ 超過しているが、反射率の中増加及び高増加ケースで はそれぞれ 16\%及び 15\%となっている。都市表面の反射率の増加によって、 地域にプラス効果が大きいといえる。

\subsection{2 緑化の影灀}

UAM シミュレーションの予測では、二酸化炭素排出の少ない榯木が気温 を減少させ (結果として光化学反忘を穞やかにする)、污染を吸収させる効 果がある。図7には、低排出緑化の高増加のケースを示している。オソン濃 度が減少するメッシュ数は増加するメッシュより多く、減少の大きさも増加 より高い。緑地増加の空気品質への影響を評価するため、式 14 で定義した オゾンの露出量の変化を調べた。表 4 ではその結果を示す。

ピーク時では，地城人口当たりオゾンに対する露出量は中増加ケースで $5 \%$ 、高増加ケースで $14 \%$ \%リフォルニア大気環境質量基淮を超えている。 国家基淮の場合、中増吸ひ螎増加ケースではそれぞれ 11\%及び $22 \%$ とな っている。

\section{4. まとめに}

本文では、都市のヒートアイランドを和らげる意義や可能性にういてその アプローチとシミュレーションカ法を検討した。特に、アメリカと世界の最 も大きく、最もスモッグが多い都市領域のうちの 1 つ、ロサンゼルス盆地を 例にして、エネルギー、気象および光化学の（空気品質）シミュレーション の結果を検討した。シミュレーションの結果として、ヒートアイランドを緩 和させることで、夏 10-20\%でスモッグは堿少できて、それはすべての自動 車の排気をコントロールすることと同じ効果である。典型的な 8 月の日のシ ミュレーションにより、ロサンゼルス盆地のクールシティ計画はオゾン濃度 の低减にネット効果があることが示唆している。被復面の高反射や緑化の増 加により、オソンのピーク濃度が 7\% (220ppb から 205ppb まで）堿る。接 地層の全体オゾン量は最大 640 トン削減できる。国家大気空気品質規格に基 ふいて、地域人口当たりオソンに対する露出超過量は、午後のピーク時間の 最高 $20 \%$ までに、冝間時間で最高 10\%に減少できる。

本文て提出した評価手法や結果は日本や世界でのヒートアイランド低㺂に よる大気質の改善に寄与することができると信じている。 